\title{
Lung Cancer by AJCC v8 Stage
}

National Cancer Institute

\section{Source}

National Cancer Institute. Lung Cancer by A/CC v8 Stage. NCI Thesaurus. Code C136467.

A term that refers to the staging of lung cancer, following the rules of the TNM AJCC v8 classification system. This staging system derives from analyses of the new retrospective and prospective databases of the International Association for the Study of Lung Cancer (IASLC). These databases contain information on patients diagnosed with lung cancer from 1999 to 2010 orig inating from 35 different databases in 16 countries around the world. This staging system applies to carcinomas of the lung, including nonsmall cell and small cell carcinomas, and bronchopulmonary carcinoid tumors. It does not apply to sarcomas or other rare tumors of the lung. (from AJCC 8th Ed.) 